\title{
Mount Fuji sign following subdural haematoma evacuation
}

\author{
Muzaffer Saglam, ${ }^{1}$ Ali Kemal Sivrioglu, ${ }^{2}$ Kemal Kara, ${ }^{3}$ Serkan Aribal ${ }^{1}$
}

${ }^{1}$ Department of Radiology, GATA HEH Teaching Hospital, Istanbul, Turkey ${ }^{2}$ Department of Radiology, Aksaz Military Hospital, Mugla, Turkey

${ }^{3}$ Department of Radiology, Beytepe Military Hospital, Ankara, Turkey

Correspondence to Dr Ali Kemal Sivrioglu, draksivrioglu@gmail.com
To cite: Saglam M, Sivrioglu AK, Kara K, et al. $B M J$ Case Rep Published online: [please include Day Month Year] doi:10.1136/ bcr-2013-009091

\section{DESCRIPTION}

An 88-year-old man was admitted to the emergency department with a head injury because of a fall. He had a loss of consciousness. Bilateral subdural haematoma and fracture of the left parietal bone were shown on the CT imaging. The left subdural haematoma was evacuated in operation and a drainage catheter was placed in the subdural space. His vital findings were normal in the postoperative period. However, the patient's general condition broke down in the postoperative sixth hour. After that, cranial CT examination was performed again. Upon CT imaging evident-increased air densities were observed in the subdural space. These findings were consistent with the Mount Fuji sign in tension pneumocephalus (figure 1). The left drainage catheter that did not work was changed in reoperation and a new drainage catheter was placed in the right subdural space. In the control CT examination, a significant decrease in the amount of air densities was observed (figure 2).

The Mount Fuji sign in tension pneumocephalus is described as bilateral subdural hypoattenuating air collections which cause compression and separation of the frontal lobes. ${ }^{1}$ The compressed frontal lobes and the widening of the interhemispheric space between the tips of the frontal lobes have the appearance of the silhouette of Mount Fuji. The most common causes of a tension pneumocephalus are evacuation of subdural haematoma, skull base surgery, paranasal sinus surgery, posterior fossa surgery in the sitting position and head trauma. ${ }^{2}$

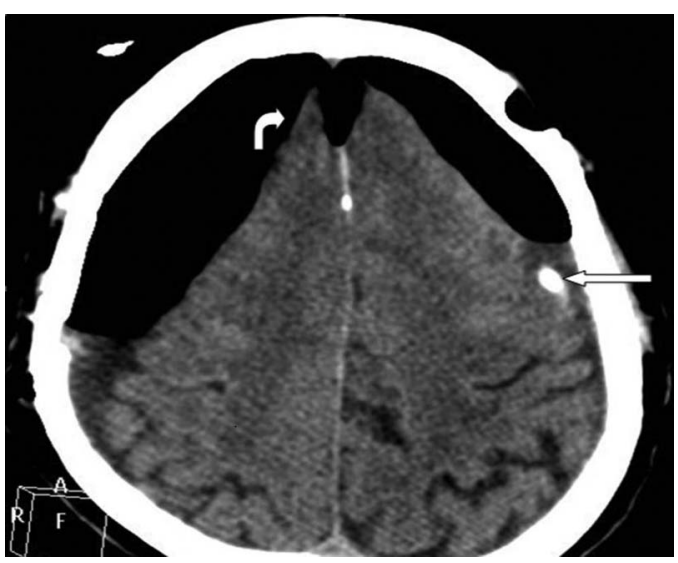

Figure 1 Axial non-enhanced CT image of brain demonstrates bilateral frontal subdural hypoattenuation with compressed and widely separated frontal lobar tips (curved arrow). Widening of the interhemispheric space between the tips of the frontal lobes is noted. Drainage catheter within the subdural space does not work (arrow).

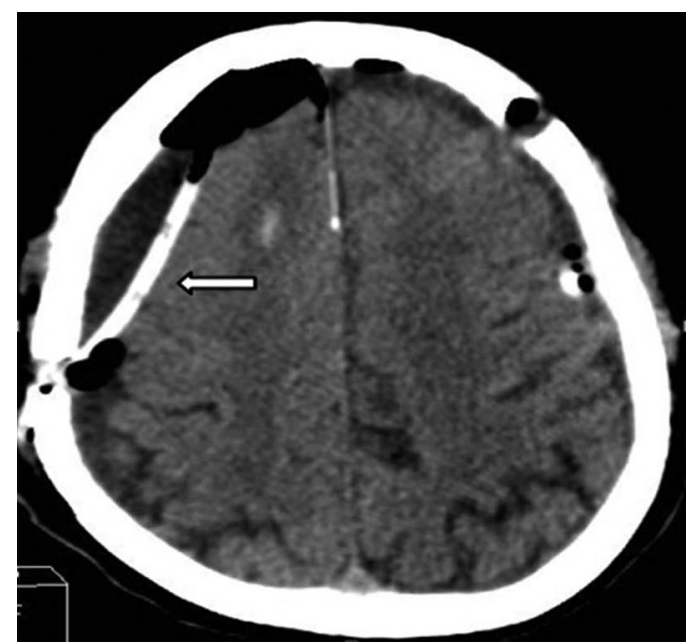

Figure 2 Axial non-enhanced CT image of brain demonstrates resolution of the air within the subdural space after inserting a second drainage catheter on the right side (arrow). Contusion in the deep white matter of the right frontal lobe considered as a new sign.

It was believed that nitrous oxide, which was used as an anaesthetic, diffused into air-filled spaces and expanded the gaseous volume. ${ }^{3}$

\section{Learning points}

- The Mount Fuji sign on CT imaging of the brain is useful for differentiating tension pneumocephalus from non-tension pneumocephalus.

- The most common causes of a tension pneumocephalus are evacuation of subdural haematoma, skull-base surgery, paranasal sinus surgery, posterior fossa surgery in the sitting position and head trauma.

Competing interests None.

Patient consent Obtained.

Provenance and peer review Not commissioned; externally peer reviewed.

\section{REFERENCES}

1 Ishiwata Y, Fujitsu K, Sekino T, et al. Subdural tension pneumocephalus following surgery for chronic subdural hematoma. J Neurosurg 1988:68:58-61.

2 Bremer AM, Nguyen TQ. Tension pneumocephalus after surgical treatment of chronic subdural hematoma: report of three cases. Neurosurgery 1982;11:284-7.

3 Artru AA. Nitrous oxides play a direct role in the development of tension pneumocephalus intraoperatively. Anesthesiology 1982;57:59-61. 
Copyright 2013 BMJ Publishing Group. All rights reserved. For permission to reuse any of this content visit http://group.bmj.com/group/rights-licensing/permissions.

BMJ Case Report Fellows may re-use this article for personal use and teaching without any further permission.

Become a Fellow of BMJ Case Reports today and you can:

- Submit as many cases as you like

- Enjoy fast sympathetic peer review and rapid publication of accepted articles

- Access all the published articles

- Re-use any of the published material for personal use and teaching without further permission

For information on Institutional Fellowships contact consortiasales@bmjgroup.com

Visit casereports.bmj.com for more articles like this and to become a Fellow 